\title{
IMAGINÁRIOS E IMAGENS: LITERATURAS E CINEMAS
}

\author{
Andréa Figueiredo Leão Grants \\ Gizelle Kaminski Corso \\ Jair Zandoná \\ Rafael Zamperetti Copetti \\ Stélio Furlan \\ Universidade Federal de Santa Catarina
}

De acordo com o calendário chinês e japonês, o ano de 2012 é o ano do Dragão, uma criatura que vislumbra o imaginário coletivo de inúmeras culturas, e que angaria para si peculiaridades inerentes ao olhar de determinados povos. No Japão e na China, por exemplo, representa a paz e é celebrado a cada Ano-Novo.

Seja na lembrança de uma serpente ou de um réptil, sua marca primordial é a luz púrpura que divisa de suas narinas. Pela luz divisada, do fogo, luz que remete à tela do cinema, vemos na imagem do dragão, analogamente, a do refletor, o emissor da verdade que se transfigura pelo olhar. É por conta desse fogo, dessa luz divisada, que escolhemos para capa da presente edição a imagem de um Dragão (sem título, técnica sumi-ê, pintura em nanquim sobre papel) elaborada pela artista Nadir Ferrari, que adotou Santa Catarina para criar raízes. Um dragão em vias de movimento, que pressupõe preparação para o ataque, atitude que precede um ritual, em posição de reverência, circundado por peixes -discípulos que o cerceiam, ciceroneiam.

O cinema inclui uma poética que está intrínseca à retina. Olhos e ouvidos atentos para o que se configura diante da imagem refletida: dragão-refletor. Luz viva, luz negra, vibrante furta-cor. Cinema, literatura, adaptar uma ação: adaptação. Diálogos. Polissemia. Vozes em movimento. 
$\mathrm{Na}$ irreverência do dragão se instala a proposta deste número temático, intitulado: "literatura e cinema", mote para a primeira seção da revista. Pensar (n)as relações que a Literatura estabelece com o cinema vai muito além dos aspectos relacionados à noção de prazer audiovisual e/ou à (falsa) ideia de que se pode facilmente dispensar a leitura de um livro ao assistir a um filme que lhe tem por base. Mitos que cercam o cotidiano na contemporaneidade. Mitos que são tangenciados nas discussões que se seguem. Ricardo André Ferreira Martins, com o artigo Cinema e literatura: algumas reflexões e considerações sobre o roteiro como gênero intersemiótico, no qual realiza análises e considerações a respeito da intersecções estéticas e estruturais, na perspectiva intersemiótica, entre o roteiro e a literatura, vislumbra desenvolver uma teoria do roteiro como gênero intersemiótico. Nessa esteira, trazemos para a baila a análise de algumas cenas do filme Force of Evil, de Abraham Polonsky, de 1948, no artigo Force of Evil e as divisões intra-classe, de Elder Kôei Itikawa Tanaka, por meio do qual são verificadas como se configura a perspectiva da esquerda sobre os monopólios e sobre o capitalismo, bem como a visão do diretor com relação à divisão intra-classes. Dois aspectos da narrativa. Duas perspectivas, assim como duas Alices, uma de Lewis Carroll, e outra de Wim Wenders, relação tangenciada por aproximações e distanciamentos no artigo de Maria Augusta Vilalba Nunes, intitulado Alice e Alice.

O artigo de Carmen Irene Correa de Oliveira, Leila Beatriz Ribeiro eValéria Cristina Lopes Wilke, O livro e a leitura no espaço da performance: o caso de "O Clube de Leitura" de Jane Austen, procura discutir o papel das narrativas fílmicas tendo o livro como objeto de representação no contexto do imaginário das formas e dos tipos de conhecimento, dos modos de organização da leitura e das práticas que têm o livro como objeto.

Em A focalização como elemento configurador da aridez relacional em "Vidas Secas", Maria Bevenuta Sales de Andrade e Charles Albuquerque Ponte comparam o uso da focalização como elemento configurador da aridez relacional no romance Vidas secas, de Graciliano Ramos e sua adaptação homônima, sob a direção de Nelson Pereira dos Santos, de 1963. E, pensando em discutir o cosmopolitismo como uma ininterrupta deriva cultural numa cartografia desterritorializada, a partir do filme Caramuru: a invenção do Brasil, de Guel Arraes, Sharmilla O'hana Rodrigues da Silva apresenta essas questões no artigo Bravura Indômita: entre a fábula e a trama.

Em perspectiva de dualidade, Bárbara Nayla Piñeiro Pessôa, em A palavra de impossível repouso: Pasolini e o olho-câmara de Murilo Mendes, estabelece um diálogo entre a teoria do cinema de Pier Paolo Pasolini e a poética de Murilo Mendes, procurando 
pensar sobre a exigência da poética do despojamento dos sentidos e o tratamento de corte e subtração conceitual quando dirigidos à palavra.

O poder da palavra, do verbo, do entrelaçamento. Palavras que também ganham força e forma na escrita calviniana, relações entre imagem e palavra, cinema e literatura, questões que são discutidas, procurando analisar em que medida a obra do escritor Italo Calvino pode ser considerada uma cartografia de palavras, em Dar a ver com palavras: cinema e literatura em Italo Calvino, de Bruna Fontes Ferraz e Maria Elisa Rodrigues Moreira. Por palavras, também, somos conduzidos ao título do artigo de Edimara Lisboa, Palavra e Utopia: Antônio Vieira missionário, no qual se discute a construção do personagem Antônio Vieira, no filme Palavra e utopia, de Manoel Oliveira, em contraste com biografias do jesuíta.

De biografias e biografemas barthesianos, rico em teor autobiográfico, Jacques Fux e Darlan Roberto dos Santos, em As muitas artes de "Santiago", de João Moreira Salles relacionam o documentário mencionado no título do texto com o personagem Santiago, procurando relacioná-lo, também, com certos personagens de Borges e Flaubert. Entre tecidos de textos e telas, Isabella Cristina Stangherlin Santucci, em O Golem na era da reprodutibilidade técnica: aparato cinematográfico, homem moderno e representação , procura pensar na figura do autômato enquanto alegoria na era da reprodutibilidade técnica, aproximando Walter Benjamin do movimento expressionista em sua forma cinematográfica e postura subversiva. Para encerrar a seção temática sobre literatura e cinema, trazemos o artigo de Maria Silvia Antunes Furtado, Ficção e subjetividade no documentário de Eduardo Coutinho, procurando analisar a construção da narrativa fílmica no documentário de Eduardo Coutinho.

A seção de Artigos com temática livre é inaugurada pelo texto de Vinícius Nicastro Honesko, intitulado Delírios II: lacerações de um corpo torturado, por meio do qual analisa a figura do poeta prometeico, percorrendo certos fragmentos do itinerário poético de Leon de Felipe. Em Mito e representação feminina em "O Forte" de Adonias Filho, Luciano Santos Neiva e Sandra Maria Pereira do Sacramento investigam os aspectos que tornam as representações de gênero como atualizadoras da redefinição da construção identitária, em contraponto ao legado fonofalologocêntrico eurodescendente, a partir da constituição do mito no texto de Adonias Filho. Para encerrar esta seção, Roselene Berbigeier Feil, no artigo $O$ processo criativo de Erico Verissimo: apontamentos em sua escrita memorialística, apresenta 
algumas considerações sobre o processo criativo do escrito gaúcho, focando-se especialmente nas obras Solo de Clarineta (volume 1) e Gato preto em campo de neve.

Referências míticas, históricas, literárias intervalam a construção das palavras da “epopeia” de Carlos Nejar em que Camões, Dante, Homero e Cervantes, por exemplo, intercalam aparições em Odysseus, o velho, leitura apresentada na seção Resenhas, de José Luiz Foureaux de Souza Júnior, sob o título, Fantasmas, influências, inspirações: Odysseus, o velho, de Carlos Nejar.

Tantas leituras de tecidos de textos, imagens, imaginários. Plural necessário para dar cor, forma e fundo a mais este número. Boa leitura!

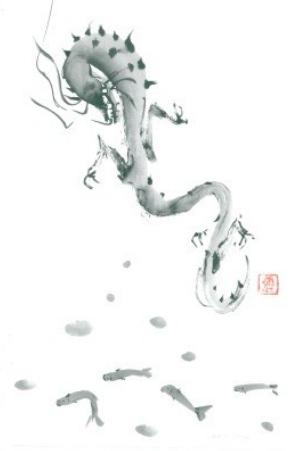

